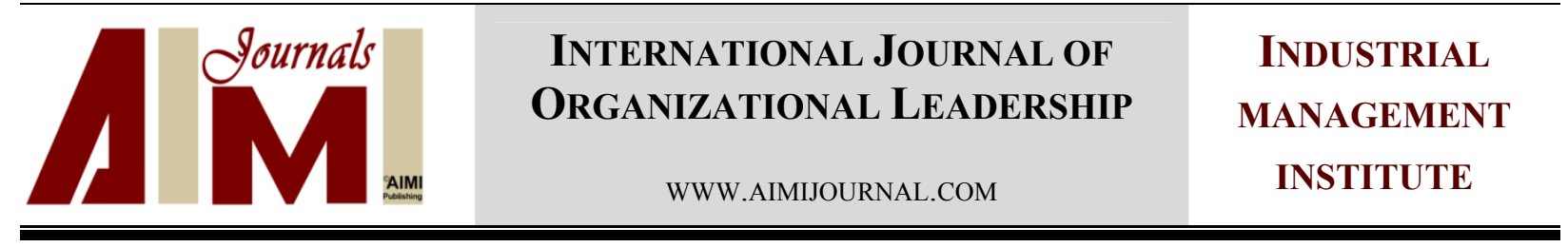

\title{
Relationship between environmental management systems implementation and environmental performance: Findings from Turkish EMS certificated businesses
}

\author{
Muhsin Halis*, Mine Halis \\ Kastamonu University, Faculty of Economics and Administrative Sciences
}

\begin{abstract}
Keywords:

EMS, EMS, ISO 14001, Business Performance, Environmental Performance

Received

18 November 2015

Received in revised form 10 April 2016

Accepted

16 April 2016

Correspondence:

mimhalis@gmail.com

Gradually, increasing environmental awareness has increased the demand for goods and services. These manufactured goods and services are made in compliance with environmental standards to protect and enhance environmental assets and natural resources as important competitive factors. Numerous standards and legal legislations have been developed to guide businesses on environmental issues. Therefore, various businesses sectors are more inclined to develop and implement environmental policies these days. Many of these policies are developed with the guidance of ISO 4001 - Environmental Management Systems (EMSs). The businesses which have adopted the standards of the EMSs have to protect the environment and ensure its continuity. Thus, businesses require the reflection of environmental management activities on businesses performance evaluation in terms of price competitiveness and cost effectiveness. To this end, this research aims to study Turkish businesses which have adopted and got EMS certification and accordingly analyze the development and implementation of EMS and how its implementation in turn affects environmental performance. Descriptive Statistics, Correlation, and Linear Regression Analyses were used to assess the association between EMS implementation and environmental performance. The results revealed that EMS implementation has a significant positive impact on environmental performance.
\end{abstract}




\section{Introduction}

The businesses that do not consider the environmental values in practice are one of the main causes of environmental concerns such as global warming, ozone layer depletion, acid rain, damages of green areas, and the rapid consume of non-renewable natural resources. There are some market influences that make the entrepreneurs more aware of the environmental values at the investment time. These market influences are consisting of conformity to national and international regulations and standards, the increasing demand for the products which protect and improve the environmental values, and prediction of the claims stating products that are not produced considering environmental issues would not be demanded in the long run. The goods and services which comply with all environmental norms are considered as crucial competitive factors like entrepreneurship quality forces at the investment phase to provide oversight and direction for environmental protection.

Today, the effects of EMS and information provision which motivate the companies to be innovative and make changes in their operating practices through adopting pollution prevention methods are not known. This study applied some reliable results for the young entrepreneurs and investors who are inclined to identify and accept natural environmental values as a force to increase price. To this end, this study tries to prove that the demand for the products that are produced without considering the environmental values would decrease. It can also claim that the application of EMS would provide competitiveness advantage which improve performance and decrease costs. Thus, more conscious entrepreneurship and success show that the compliance of ISO 14001 EMS standards from the beginning would lead to the high performance.

\section{The Literature Review}

Currently, businesses form certain strategies under the influence of globalization, technological changes, and sustainable development and environmental protection. Environmental strategies result from the right combination of provocative strategies which refer to the new opportunities and anticipation and accordingly certain actions for future needs (Li, Zhang, \& Chan, 2005). With the increased sensibility to the environmental values, these developmental strategies reflect the proper combination of natural resources and environmental protection and improvements. The sustainability of renewable and unrenewable resources and their protection and improvement in natural environments will be possible if entrepreneurial decisions adopt environmental approach and act accordingly.

Environmental issues are no longer considered as a cost element. Instead, they change into the urgent elements to build the sustainable world, advance business image, and improve reliability and performance. ISO has launched EMS standards to avoid different applications in variety different countries and standardization activities. Thus, institutions and organizations perform their environmental activities with guidance of ISO 14001 EMS standards. Application of ISO 14001 EMS standards inevitably increases costs of institutions and organizations. Table1 summarizes the literature review on the benefits of ISO 14001 . Table 1 depicts that the benefits of successful EMS implementation are too broad and extensive. Therefore, these benefits are much more important than the cost increase. 
Gavronski, Ferrer, and Laureano Paiva (2008) divided the benefits of ISO 14001 EMS standards into the four different categories including operational changes, financial effects, financial partners, and social partners and relations. Sambasivan and Fei (2007) stated that the reconceptualised categories can improve the business reputation and the image and the employees' moral motivation and increase the business performance and profitability, customer satisfaction, as well as reliability of such institutions.

Table 1

The Summary of Literature Review on the Benefits of ISO 14001

\begin{tabular}{|c|c|}
\hline $\begin{array}{l}\text { Increase in Market } \\
\quad \text { Share }\end{array}$ & $\begin{array}{l}\text { - It provides access international markets and increase in national market share (Petroni, 2001). } \\
\text { - It improves in direct competition (Leal, Fa, \& Pasola, 2003). } \\
\text { - It increases market share (Tan, 2005). } \\
\text { - It provides important opportunities to gain competitive advantage. } \\
\text {-It becomes one of the indispensables in sustainability and competitiveness in trade. }\end{array}$ \\
\hline $\begin{array}{l}\text { Increase the Morale and } \\
\text { Motivation of } \\
\text { Employees }\end{array}$ & $\begin{array}{l}\text { - It increases motivation and develops the cooperation between employees and administration (Petroni, } \\
\text { 2001; Sambasivan \& Fei, 2007). }\end{array}$ \\
\hline $\begin{array}{l}\text { Increase Customer } \\
\text { Loyalty and Trust }\end{array}$ & $\begin{array}{l}\text { - It increases the reliability of financial institutions (Zutshi \& Sohal, 2004). } \\
\text { - It increases the customer loyalty and trust (Chittaie, 2012; Sambasivan \& Fei, 2007). } \\
\text { - It ensures customer satisfactions (Hui, Chan, \& Pun, 2001). }\end{array}$ \\
\hline $\begin{array}{l}\text { Cost Reduction, } \\
\text { Increased efficiency in } \\
\text { Operations and } \\
\text { Processes }\end{array}$ & $\begin{array}{l}\text { - It reduces the environmental management cost, the waste product and insurance cost. It also provides } \\
\text { supply saving in recycling, energy-saving (Petroni, 2001). } \\
\text { - As a result of the reduction on waste product, the costs are reduced. By means of recycling, the positive } \\
\text { results such as savings in electricity, water, gas and raw material as well as the increase in quality are } \\
\text { ensured (Zutshi \& Sohal, 2004). } \\
\text { - EMS enables the effective use of the resources (Leal, Fa, \& Pasola, 2003). } \\
\text { - It initiates a cleaner/green and more productive process (Tan, 2005). } \\
\text { - It enables cost-reduction (Petroni, 2001). } \\
\text { - The effective use of the sources reduces the cost (Hui, Chan, \& Pun, 2001). } \\
\text { - It provides fund saving and reduces the waste product (Zeng, Tam, Tam, \& Deng, 2005). } \\
\text { - It reduces the cost and increases profitability in long run. }\end{array}$ \\
\hline $\begin{array}{l}\text { Increase the Reputation } \\
\text { of the Business }\end{array}$ & $\begin{array}{l}\text { - Environmental responsibilities positively contribute to business image (Petroni, 2001). } \\
\text { - Eco-friendly business image enables better relationship with partners, customers and society (Zutshi \& } \\
\text { Sohal, 2004). } \\
\text { - It positively contributes to the business image (Leal, Fa \& Pasola, 2003). } \\
\text { - It positively contributes to the business image as well as popularity/reputation (Sambasivan \& Fei, 2007). } \\
\text { - It advances the business image (Tan, 2005). } \\
\text { - It advances the commercial image of the business for marketing (Zeng, Tam, Tam, \& Deng, 2005). }\end{array}$ \\
\hline
\end{tabular}

Improvements in Risk Management Practices

It provides improvements in risk management and better preparation for emergencies (Petroni, 2001).

- It increases the profitability of institutions and organizations (Sambasivan \& Fei, 2007).

- It increases the financial performance (Gavronski, Ferrer, \& Laureano Paiva, 2008).

Performance and Increase Profitability

- The costs of EMS do not negatively affect the financial performance (Watson, Klingeberg, Polito, \& Guerts, 2004).

- It positively contributes to the financial performance. Specifically, it increases the performance in terms of economic elements, environmental factors and customer satisfaction (Ann, Zailani, \& Wahid, 2006).

- It provides an opportunity to increase environmental as well as institutional performance.

The research on business environmental performances such as reduction of greenhouse gas, reduction of emissions, and the reduction in detrimental flow result in positive environmental impacts. Many investors claimed that these activities reduce the cost and therefore positively affect on business performance (Al-Tuwaijri, Christensen, \& Hughes, 
2004; Hart \& Ahuja, 1996; King \& Lenox, 2001). The environmental effect of manufacturing practice attracts the attention of the customers as well as reducing energy consumption and waste products. Environmental performance refers to the management relations among natural environment, products, and services. As a result, the reduction of the environmental impacts in organizations increases the environmental performance.

In organizational level, there is a need for various education programs to have a successful environmental performance. Environmental education provides organized efforts which systematically improve performance and knowledge effectively. This implies that there is a direct environmental education for both employees and managers. Environmental sensibility requires awareness and this awareness and knowledge provide ground to tackle environmental issues effectively. Environmental education also reduces the cost of products and provides a safe working environment for the employees. Each educational level is vital for the success of the environmental education programs specifically education for the managers seems to be important to support environmental decisions. Therefore, it is possible to claim that environmental education programs are positively correlated with environmental management expertise and performance.

A successful environmental performance tries to enhance decision-making authority since the results requires full participation. Therefore, any initiative activity that does not have quality and full participation inevitably doomed to failure. Therefore, there is a direct relationship between team-based educational programs and performance. A research was conducted in USA in corporations which have ISO 14001 certification and found out that environmental issues in teamwork have a great impact on the effectiveness of EMS education. Thus, it is possible to claim that effective teamwork is useful for improving environmental performance.

The environmentally consciousness process and environmental planning and management over the last years led the businesses to receive certification of ISO14001, invest more environmental activities, and develop eco-friendly products. In recent years, many businesses not consider the environmental investment as a cost but rather as a strategy which leads to the firms' success. The environmental consciousness and accordingly the business environmental activities are seen as strategically important factors which influence on the commercial performance.

Some studies investigated the relationship between environmental performance and commercial performance to determine whether environmental performance or economic performance influence on financial, environmental, and economic performances. According to Schultze and Trommer (2012), structural organization of a business and its environmental/social implications have important role. The factors such as social responsibility, environmental politics, and activities and programs play important role in creating social impact and direct social relations.

EMS is considered as an important tool for monitoring, evaluating, and developing firms' environmental performances. This system, at the same time, provides important data and knowledge of current situation; therefore, it substantially contributes to the evaluation of the current performance (Daryani, Ali, \& Asli-zadeh, 2012; Jasch, 2000). The initial role of the environmental performance evaluation is the extensive environmental analysis of an 
innovation. The proposed environmental indicators focus on concrete activities in terms of performance evaluation. Environmental indicators not only evaluate but also provide the data from environmental application (Jasch, 2000). These indicators make it possible to determine the targets and control areas through suppressing any negative inclination in the process of environmental control.

Organizational activities are defined as the supply and distribution of physical facilities and equipments during the production process (Jasch, 2000). Environmental indicators are used to evaluate the inputs including physical facilities and equipments. They are used to evaluate design, maintenance supply, energy, products, services, waste products and emission, developing materials, and delivery of products. Some previous studies proposed some certain criteria regarding environmental activities such as environmental design which contribute to the environmental performance (Jasch, 2000; Kuhre, 1998), energy consumption which consider as an indicator of environmental activities (Jasch, 2000; Tibor, 1996), and the maintenance of the materials which contribute to the development of an effective and operational environmental performance. Since air pollution, noise pollution, garbage, and sewage are the four basic environmental problems, it is necessary to pay more attention to these issues and minimize the occurrence of these four problems (Jasch, 2000; Kuhre, 1998).

Environmental performance indicators could be defined as the set of variables that are used to evaluate the results of projects' performance in terms of their effectiveness and productivity. Some activities such as cleaning the locations directly affect the environmental performances. Secondly, minimum standards for environmental protection should be included into environmental key performance indicators (Jasch, 2000; Thoresen, 1999). Environmental control activities are also important in terms of monitoring and controlling the quality of environmental performance (Jasch, 2000). Table 2 presents three basic indicators of environmental activities and performances.

Table 2

The Basic Indicators of Environmental Activities \& Performances

\begin{tabular}{lc}
\hline Environmental Operational Indicators & Environmental Performance Indicators \\
\hline Environmental Site Planning & Site Environment \\
Energy Consumption & Regulatory Compliance \\
Maintenance of Equipment & Auditing Activity \\
Air Pollution Control & \\
Noise Pollution Control & \\
Water pollution Control & \\
Waste pollution Control & \\
\hline
\end{tabular}

Environmental investments are, traditionally, considered as an additional cost for the businesses (Palmer, Oates, \& Portey, 1995; Walley \& Whitehead, 1994). Companies should invest in eco-friendly cleaning materials to minimize the environmental impacts of the factories to adopt environmental laws. Porter and van der Linde (1995) and Porter (1991) attempted to approach this issue from a different perspective. Following Porter's view, other reformists aimed to maximize the benefits of the businesses through environmental design. 
Companies admit that pollution is in reality a non-recoverable matter or cost for manufacturing processes (Shrivastava \& Hart, 1995).

Initial studies such as Chen and Metcalf (1980) and by Spicer (1978) were undertaken to focus on and assess the pollution inputs. These studies aimed to mirror the relationships between financial performance and environmental performance. Spicer (1978) found out that there was a positive correlation between financial performance and environmental performance and this proposition was proved by Chen and Metcalf (1980). However, Mahapatra (1984) concluded, on the contrary, by using a larger sample and time period and later Jaggi and Freedman (1992) reported similar findings. Current studies use more appropriate statistical techniques as well as more broad set of environmental techniques and financial variables. Studies conducted in 1990's use cross-sectional study data and design (Hart \& Ahuja, 1996; Russo \& Fouts, 1997), but over the next decade, panel data analysis became increasingly popular. Russo and Fouts (1997) stated that a better environmental performance, which adapt to the environmental regulations and seek ways to minimize the waste, is related to better financial performance and profitability. One of the most cited studies was conducted by Hart and Ahuja in 1996 who found evidence of association between emission reduction and financial performance. Using production samples, they stated that manufacturing companies and mining factories during the years 1989-1992 found profit through the use of environmental awareness and social programs. According to their analysis, profitability as well as profit on sale increase when the emissions are minimized. After minimizing, capital and equity profitability occurred within 2 years.

\section{Research Hypothesis}

In line with the discussion above, the following main research hypothesis was formulated:

$\mathbf{H}_{1}$ : There is a significant relationship between the implication of EMS and the performance of the business?

\section{Method}

The questionnaire used is consisted of 4 parts. First part includes details related the company. The second part consists of 11 questions regarding Decision to Get ISO 14001 EMS Certification $(\alpha=0.96)$. These questions were turned into a questionnaire for the first time for this research by a researcher due to a literature research. Third part is comprised of 15 questions involving Environmentalist Implementations by Companies again created for the first time for this research by the said researcher $(\alpha=0.98)$. Fourth part contains the Environmental Performance Scale comprised of 19 questions. The scale measuring the environmental performance was created for this research for the first time. The remaining 19 items were prepared in Likert scale in seven $(\alpha=0.96)$.

To ensure content validity, an extensive literature review was done. First, an initial pool of 43 variables was developed. These items were submitted to a panel of expert judges, together with the definitions of all the dimensions of the scale. The experts were asked to rate each of the 69 items in the initial pool to indicate the extent to which it represented the specific dimension. Seventeen factors were thus omitted from the item pool due to similarity with other variables as well as non-consistency with the scope and the content of 
the research and only 26 variables were remained. Nineteen factors were rated according to a 7-point Likert scale ranging from 1 (strongly disagree) to 7 (strongly agree). The number of participants for factor analysis discussed differently in previous studies. Some of them determined or defined the participant size based on the number of person, and some others based on the rate of item/person. There is an agreed opinion in all researches that the participant number should be bigger than the number of items (Bryman \& Cramer, 2005; Cohen, Manion, \& Morrison, 2007). They accepted that the sample size should be 5 times larger than the item number.

Table 3

The Results of the Factor Analysis of Environmental Performance

\begin{tabular}{|c|c|c|c|c|c|c|}
\hline \multirow[t]{2}{*}{ Factors } & & \multicolumn{5}{|c|}{ Correlation } \\
\hline & & $\mathrm{M}$ & SD & EMI & EMS & Factor Loading \\
\hline \multirow{9}{*}{$\begin{array}{c}\text { Factor 1: Activity Performance } \\
\text { (37,977 Percent of Variance; } \\
\text { Alpha: 0.94) }\end{array}$} & The Rate of Recycling of Materials & 3.41 & 1.59 & $0.75^{*}$ & $0.69^{*}$ & 0.803 \\
\hline & The Use of Recycling Materials & 3.65 & 1.56 & $0.72^{*}$ & $0.63^{*}$ & 0.794 \\
\hline & Work Accidents that Have Environmental Effect & 3.22 & 1.74 & $0.79^{*}$ & $0.84^{*}$ & 0.770 \\
\hline & The Waste Rate per Unit Product & 3.28 & 1.40 & $0.77^{*}$ & $0.79^{*}$ & 0.734 \\
\hline & The Noise Level & 3.26 & 1.27 & $0.69^{*}$ & $0.66^{*}$ & 0.728 \\
\hline & The Quantity of Input per Unit Product & 3.79 & 1.09 & $0.68^{*}$ & $0.65^{*}$ & 0.644 \\
\hline & Environmental Complaints & 3.37 & 1.74 & $0.71^{*}$ & $0.74^{*}$ & 0.639 \\
\hline & Error and Loss Rate & 3.57 & 1.36 & $0.54^{*}$ & $0.63^{*}$ & 0.626 \\
\hline & Total Cost & 3.64 & 1.13 & $0.59^{*}$ & $0.65^{*}$ & 0.581 \\
\hline \multirow{8}{*}{$\begin{array}{c}\text { Factor 2: Competitive } \\
\text { Performance } \\
\text { (35,648 Percent of Variance; } \\
\text { Alpha: } 0.96)\end{array}$} & Profitability & 3.53 & 0.99 & 0.60 & 0.69 & 0.90 \\
\hline & Sale Revenues & 3.64 & 1.04 & $0.58^{*}$ & $0.68^{*}$ & 0.72 \\
\hline & The Rate of Capacity Utilization & 3.62 & 1.17 & $0.72^{*}$ & $0.72^{*}$ & 0.72 \\
\hline & Production Efficiency & 3.49 & 1.22 & $0.75^{*}$ & $0.72^{*}$ & 0.69 \\
\hline & Consumer Loyalty & 3.40 & 1.44 & $0.70^{*}$ & $0.73^{*}$ & 0.67 \\
\hline & Product Quality & 3.62 & 1.36 & $0.66^{*}$ & $0.67^{*}$ & 0.64 \\
\hline & The Opportunities to Access New Market & 3.46 & 1.29 & $0.67^{*}$ & $0.76^{*}$ & 0.63 \\
\hline & The Reputation of the Business & 3.05 & 1.74 & $0.86^{*}$ & $0.92^{*}$ & 0.59 \\
\hline \multicolumn{7}{|c|}{$\begin{array}{l}\text { Extraction Method: Principal Component Analysis. Rotation Method: Varimax with } \\
\text { Kaiser Normalization. Rotation Converged in } 3 \text { Iterations. *. Correlation is significant } \\
\text { at the } 0.01 \text { level (2-tailed). }\end{array}$} \\
\hline
\end{tabular}

The statistical population of this study consisted of the businesses with EMS certification. In order to collect the data and to test the main hypothesis of the study, a questionnaire was developed and distributed among participants. From 170 questionnaires which were sent to all businesses, 21 of them were left out due to their data insufficiency and only 147 of them were used for the analysis. To ensure content validity, an extensive literature review was done and the expert consultation was done in the context of the items of the scale. To ensure the construct validity, explanatory factor analysis was done. Before running factor analysis, several presumptions were checked to see that the dataset was suitable for factor analysis such as Kaiser- Meyer-Olkin (KMO) Measure of Sampling Adequacy coefficient and Bartlett's Sphericity test. The Kaiser-Meyer-Olkin Measure of Sampling Adequacy tested whether the partial correlations among variables were small or not. High values (close to 1.0) generally indicated that a factor analysis might be useful with data. Bartlett's Sphericity test also tested that the hypothesis and stated that the correlation matrix was not an 
identity matrix and therefore they were applicable to factor analysis (Chi-Square $=340.31 ; \mathrm{p}$ $<0.00)$. Here, the rejection of the hypothesis implied to the correlation between variables. In this research, the result of KMO test is calculated as 0. 91. Table 3 shows the results of the factor analysis of environmental performance.

\section{Results}

To analyze data and test the variables, both descriptive and inferential statistical analysis were used. SPSS 16 software was used to analyze research data. Table 4 presents the summarized demographic information for study participants.

Table 4

The Summarized Demographic Information of Study Participants

\begin{tabular}{|c|c|c|c|}
\hline & & Frequency & Percent \\
\hline \multirow[t]{4}{*}{ The Number of Employees } & $1-49$ & 21 & 13,7 \\
\hline & $50-249$ & 42 & 27,5 \\
\hline & 250 and more & 90 & 58,8 \\
\hline & Total & 153 & 100 \\
\hline \multirow[t]{3}{*}{ Foreign Sale Activities } & Yes & 141 & 92,2 \\
\hline & No & 12 & 7,8 \\
\hline & Total & 153 & 100 \\
\hline \multirow{4}{*}{$\begin{array}{l}\text { How Long Do You Have the License of ISO } 14001 \\
\text { EMS? }\end{array}$} & February & 45 & 29,4 \\
\hline & May & 60 & 39,2 \\
\hline & 6 and more & 48 & 31,4 \\
\hline & Total & 153 & 100 \\
\hline \multirow[t]{4}{*}{ The Length of the Process of Getting EMS License } & $1-12$ month & 114 & 74,5 \\
\hline & 13-24 month & 33 & 21,6 \\
\hline & 24 & 6 & 3,9 \\
\hline & Total & 153 & 100 \\
\hline \multirow[t]{4}{*}{ The Length of the Activity Period of the Firm } & 1.Eki & 6 & 3,9 \\
\hline & Kas.20 & 45 & 29,4 \\
\hline & 21 and more & 102 & 66,7 \\
\hline & Total & 153 & 100 \\
\hline \multirow[t]{3}{*}{ Do You Have QMS License before EMS? } & Yes & 147 & 96,1 \\
\hline & No & 6 & 3,9 \\
\hline & Total & 153 & 100 \\
\hline \multirow[t]{4}{*}{ The Market Knowledge of the Firm } & National $>\% 50$ & 75 & 49 \\
\hline & Foreign $>\% 50$ & 60 & 39,2 \\
\hline & National $=$ Foreign & 18 & 11,8 \\
\hline & Total & 144 & 94,1 \\
\hline
\end{tabular}

This systematic data classification allows the readers to comprehend the study better. During the sampling phase, the total number of businesses that certified EMS was determined. According to the data obtained by Turkish Standard Institute (TSI), it is confirmed that the total number of businesses that have TS EN ISO 14001 certifications is 
305. As shown in Table 4, the sectorial distribution of these businesses percentages is presented.

As well as Texas Success Initiative (TSI), other national and international accredited organizations are also authorized to certify. In Turkey, TSI is chosen more than other organizations for certification. Moreover, the businesses which concentrate on food, machine, construction, and chemistry sectors are more likely to use TS EN ISO 14001 certification. Due to the European integration process, the raising environmental awareness of the consumers and the demand for having a TS EN IS0 14001 certification are expected to increase. The extent EMS application which affects the overall business performance is analyzed under four performance categories including production performance, financial performance, social performance, and competitive performance. The variables that affect the overall business performance are conceptualized as a set of variables which is related to the environmental performance.

Table 5

Factors that Affect Companies’ Motivation and Decision to Get ISO 14001 EMS Certification

\begin{tabular}{|c|c|c|c|c|c|}
\hline \multirow[b]{2}{*}{ The Motivations to Have EMS (Cronbach's Alpha: 0.96) } & \multicolumn{2}{|c|}{ Descriptive Statistics } & \multicolumn{3}{|c|}{ Correlations* } \\
\hline & Mean & Std. Dev. & EMI & AP & $\mathrm{CP}$ \\
\hline Contributing to the Image of the Business & 3.34 & 2.12 & $0.54 *$ & $0.41^{*}$ & $0.47^{*}$ \\
\hline Increasing the Ability of Innovative Capability & 3.33 & 1.97 & $0.67 *$ & $0.41^{*}$ & $0.47 *$ \\
\hline Minimizing Cost & 3.29 & 1.89 & $0.44 *$ & $0.29 *$ & $0.55^{*}$ \\
\hline Adopting the Legal Regulation & 3.12 & 2.24 & $0.81 *$ & $0.79 *$ & $0.32 *$ \\
\hline Meeting the Expectation of Partners & 3.10 & 1.70 & $0.82 *$ & $0.59 *$ & $0.57 *$ \\
\hline Improving the Quality of Products & 3.10 & 1.93 & $0.62 *$ & $0.44^{*}$ & $0.46^{*}$ \\
\hline Providing Competitive Advantage & 3.03 & 1.97 & $0.79 *$ & $0.64 *$ & $0.51^{*}$ \\
\hline Meeting the Expectations of Related Organizations & 2.93 & 1.36 & $0.77 *$ & $0.60 *$ & $0.44 *$ \\
\hline Systematizing Environmental Practices & 2.80 & 2.28 & $0.85 *$ & $0.71 *$ & $0.42 *$ \\
\hline Creating New Market Opportunities & 2.76 & 2.14 & $0.87 *$ & $0.70 *$ & $0.46^{*}$ \\
\hline Raising Profitability & 2.71 & & $0.82 *$ & $0.71 *$ & $0.46^{*}$ \\
\hline
\end{tabular}

EMI: Environmental Management Implications

AP: Activity Performance CP: Competitive Performance *Correlation: Significant level is 0.01 (2-tailed).

In this section, intentions, activities, and implementations of EMS as well as the results of its application are presented within the framework of descriptive statistics. Initially, the motivation and the intention of having EMS certification are analyzed. Evaluating environmental performance and accordingly the business performance is related to the intention of having EMS certification. In order to answer the first research question, the factors that effect on the companies' motivation and decision to get ISO 14001 EMS certification are presented in Table 5.

The results of the questionnaire on the motivations of having EMS certification showed that the highest scores among motivational factors were raising profitability, adopting legal institutions, and increasing the ability of innovative capability. Table 6 shows the environmental implications of companies. 
Table 6

Environmental Implications of Companies

\begin{tabular}{lccccc}
\hline Environmental Implications (Cronbach's Alpha: 0.98) & \multicolumn{2}{c}{ Descriptive Statistics } & \multicolumn{3}{c}{ Correlation Analysis } \\
& Mean & Std. Dev & EMI & AP & CP \\
\hline The Progressive Recovery of EMS Process & 3.55 & 1.25 & $0.57^{*}$ & $0.34^{*}$ & $0.60^{*}$ \\
Easily Evitable Project Design & 3.38 & 1.20 & $0.54^{*}$ & $0.29^{*}$ & $0.61^{*}$ \\
The Works to Decompose the Waste Products & 3.36 & 1.32 & $0.62^{*}$ & $0.39^{*}$ & $0.75^{*}$ \\
Manufacturing New Easily Recycling Products & 3.32 & 1.69 & $0.56^{*}$ & $0.41^{*}$ & $0.74^{*}$ \\
Allocation of Sufficient Resources for EMS by Top Managers & 3.30 & 1.59 & $0.57^{*}$ & $0.39^{*}$ & $0.68^{*}$ \\
Use of Returnable Package after Usage & 3.30 & 1.33 & $0.68^{*}$ & $0.46^{*}$ & $0.80^{*}$ \\
Recycling of Composed Waste Products (such as financial) & 3.27 & 1.38 & $0.72^{*}$ & $0.37^{*}$ & $0.77^{*}$ \\
Allocation of Time and Resources for EMS Implications & 3.22 & 1.60 & $0.35^{*}$ & $0.26^{*}$ & $0.47^{*}$ \\
Use of Eco-friendly Package Materials & 3.22 & 1.46 & $0.58^{*}$ & $0.32^{*}$ & $0.68^{*}$ \\
The More Use of Recycling Input for Production & 3.14 & 1.50 & $0.63^{*}$ & $0.41^{*}$ & $0.81^{*}$ \\
The Replacement of Environmentally Problematic Inputs & 3.00 & 2.02 & $0.68^{*}$ & $0.37^{*}$ & $0.76^{*}$ \\
The Evaluation and Reporting of Environmental Performance & 2.96 & 2.34 & $0.74^{*}$ & $0.39^{*}$ & $0.82^{*}$ \\
The Regular Team-work on Environment & 2.92 & 2.00 & $0.74^{*}$ & $0.41^{*}$ & $0.84^{*}$ \\
The Announcement of EMS Results to the & 2.85 & 2.15 & $0.75^{*}$ & $0.34^{*}$ & $0.84^{*}$ \\
Regular Training for EMS Education & 2.84 & 1.94 & $0.72^{*}$ & $0.43^{*}$ & $0.88^{*}$ \\
* Correlation is significant at the 0.01 level (2-tailed). & & & & & \\
EMI: Environmental Management Implications AP: Activity Performance & CP: Competitive Performance & \\
\hline
\end{tabular}

Based on the literature review, the business implications of EMS are classified within two groups, namely environmental design and ecological solid waste. Environmental design is divided into three categories including EMS management support, EMS education, and EMS performance evaluation and reporting. Ecologist solid waste, on the other hand, is divided into two categories, namely waste minimization and recycling practices. Factor analysis combined variables gathered to create a meaningful whole (a smaller set of factors) and presented a consistent classification which represented a hypothetic variable. In factor analysis. 19 observed variables were gathered under 2 aspects of business environmental performance including activity performance which explained 37.72 per cent of variance and included 10 variables and competitive performance which referred to the competitive capacity of the business included 35.64 per cent of the variance. The factor construct explained 73.37 per cent of the variance and showed the high capacity of factor analysis. In the first construct of the model, performance indicators were evaluated under the sub-categories of financial performance, competitive performance, production performance and social performance. Nonetheless, statistical tests of the research data presented the unqualified character of this model construct. The result of the factor analysis of the performance indicators indicted that two-aspect model was more applicable. As a result, the new model and relationship between the investigated variables were tested by regression analysis. Figure 1 presents the correlations among the research variables. 


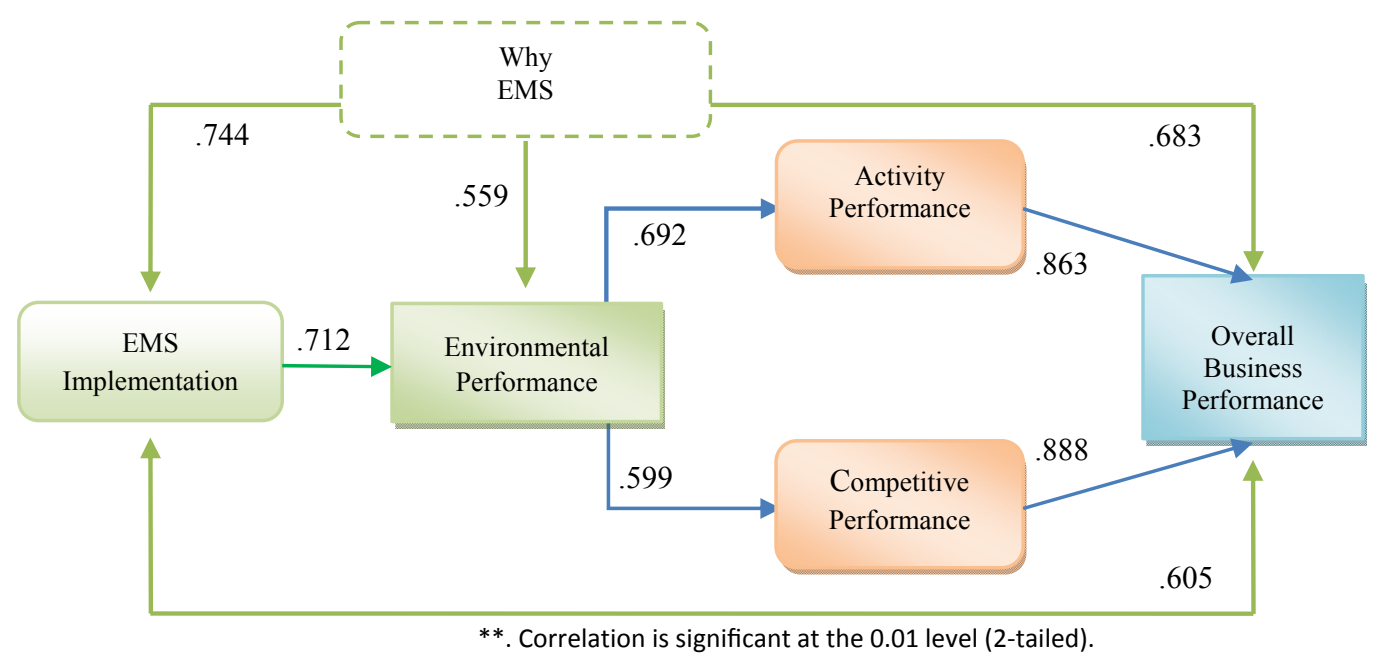

Figure 1. The correlations among the research variables

\section{Discussion and Conclusion}

The findings of the study revealed that there was significant positive correlation between EMS implementation and business performance. They were consistent with the results of previous studies on Turkey's businesses operations. The results of correlation analysis stated that EMS implementation had a positive impact on consumers' loyalty, business reputation, opportunities for new markets, and product image. In fact, it is argued that EMS provides the access to international markets and increases the national market share because EMS certification plays an important key in the international trade businesses. Furthermore, it would also provide all possible assistance to boost the businesses regarding the release of multi-faceted permit and registration and supervision of international trade. Both national and international customers might also expect the businesses meet their environmental necessities or needs. At the same time, factors such as progress in some key environmental issues, establishing and maintaining good relationships in society, and raising the customers' confidentiality were also operating under the guidance of EMS standards. A business having EMS implementations sends important messages to its partners and customers to protect the environment. Clean and safe production environment increases the loyalty and confidentiality of customers. Implementing EMS standards usually reduced the cost because it enabled a more efficient use of raw material, energy, and labour costs. The process progress increased the safety and decreased the cost of waste material suppression as well as using recycled materials. Furthermore, implementation of EMS decreased the insurance cost and the statistical results of environmental performance and EMS implementations showed a significant high correlation.

Companies consider EMS as an image-making factor to increase competitive capacity. Aligned with the environmental responsibility, the legitimacy of business processes and image of the businesses are developed. Eco-friendly products enable companies to improve their relationships with customers, society, and other partners. As the environmental risks decrease, businesses become more attractive for present and potential customers. Some 
businesses use environmental pressure to develop operational productivity, business image, and new products and opportunities and therefore they gain competitive advantage. EMS also provides an opportunity to acquire business undertaking and develop environmental performance for the customers. Partners, insurance businesses, and financial institutions. ISO 14001 EMS implementation is practiced on a voluntary basis. It is seen that customers of foreign and national markets want to buy products and services that get EMS standards. In addition, the international business relations field is also requires ISO 14001 EMS standardized products and services. These reasons show that the implementation of ISO 14001 EMS standards ensures environmental sustainability and competitive advantage and increases the demand for the EMS standardized products and services. An increase in demand provides an increase in market share and sales revenue; therefore, the financial performance of the business is increased. ISO 14001 EMS standards play an important role in developing good relationships with all groups; for example EMS cooperative provides a range of activities and measurements to help managers and the employees and increases the employees' mood and motivation to build and maintain company's loyalty and reputation in the eyes of the public, customers, and other partners through providing an eco-friendly image.

The implementation of EMS standards enables a more efficient use of raw materials, energy, and labour and therefore increases productivity. The increasing productivity reduces the cost and decreasing waste materials provides the waste suppression cost. The waste materials are recycled and recycling materials are used as new inputs in place of waste ones. Therefore, the potential legal punishment is also avoided or justified. Factors such as increasing productivity, saving material, releasing waste suppression cost, and avoiding legal punishment directly increase the financial performance. It is obviously known that EMS standards have positive impact on the environmental performance of the businesses due to proving waste-reduction, recycling, and clean technology. In order to strengthen and back up the findings and conclusions in this study, it is essential to implement further research in this regard. Considering the research findings, some suggestions are proposed. To increase the interest for ISO 14001 EMS, the benefits of this certification body should be discussed considering the magnitude of current environmental issues in scientific and cultural activities where both producers and consumers participate. Moreover, the chambers of industry and commerce should announce the implication changes of EMS certification in businesses as well as their positive impact on business performance to inspire and encourage the other businesses. Clean productions, furthermore, adopt themselves to suppress the main sources of pollution instead of controlling pollution. Consumers should be trained about EMS because the main goal of production is to offer products and services to the consumers. This training implies a supplementary movement contributing to the solutions of real environmental problems. Also. ISO 14001 EMS should be taken as one of the indispensable aspect of investment initiations as well as improving current investments. Finally, since every individual might be the future entrepreneur, environmental issues and preventive factors should be included within the content of an elective course of all physical sciences programs. On the other hand, in case of the social sciences programs, the course should be offered as a non-area elective one; therefore, it should become a basic part of each educational program. 


\section{References}

Al-Tuwaijri. S., Christensen. T. E., \& Hughes II. K. E. (2004). The relations among environmental disclosure, environmental performance, and economic performance: A simultaneous equations approach. Accounting Organizations \& Society. 29(5/6), 447-471.

Ann. G. E., Zailani. S., \& Wahid. N. A. (2006). A study on the impact of EMS (EMS) certification towards firms' performance in Malaysia. Management of Environmental Quality: An International Journal. 17(1), 73-93.

Bryman. A., \& Cramer. D. (2005). Quantitative data analysis with SPSS 12 and 13: A guide for social scientists. Hove: Routledge.

Chen. K. H., \& Metcalf. R.W. (1980). The relationship between pollution control record and financial indicators revisited. The Accounting Review. 55(1), 168-177.

Chittaie. R. (2012). Customer relationship business management and business strategies. International Journal of Organizational Leadership. 1(1), 13-22.

Cohen. L., Manion. L., \& Morrison. K. (2007). Research methods in education (5 $5^{\text {th }}$ ed.). New York: Routledge Falmer.

Daryani. S. M., Ali. S., \& Asli-zadeh. A. (2012). Organizational theory, systemic thinking and system management. International Journal of Organizational Leadership. 1(2), 71-79.

Gavronski. I., Ferrer. G., \& Laureano Paiva. E. (2008). ISO 14001 certification in Brazil: Motivations and benefits. Journal of Cleaner Production. 16, 87-94.

Hart. S. L., \& Ahuja. G. (1996). Does it pay to be green? An empirical examination of the relationship between emission reduction and firm performance. Business Strategy \& the Environment. 5, 30-37.

Hui. I. K., Chan. A. H. S., \& Pun. K. F. (2001). A study of the EMS implementation practices. Journal of Cleaner Production. 9, 269-276.

Jaggi. B., \& Freedman. M. (1992). An examination of the impact of pollution performance on economic and market performance: Pulp and paper firms. Journal of Business Finance Accounting. 19(5), 697-713.

Jasch. C. (2000). Environmental performance evaluation and indicators. Journal of Cleaner Production. 8(1), 79-88.

King. A. A., \& Lenox. M. J. (2001). Does it really pay to be green? An empirical study of firm environmental and financial performance. Journal of Industrial Ecology, 5(1), 105- 116.

Kuhre. W. L. (1998). ISO 14031 - environmental performance evaluation (EPE): Practice tools and techniques for conducting an environmental performance evaluation. Upper Saddle River. NJ. : Prentice Hall PTR.

Leal. G. G., Fa. M. C., \& Pasola. J.V. (2003). Using environmental management systems to increase firms' competitiveness. Corporate Social Responsibility \& Environmental Management. 10(2), 101-110.

Li. H., Zhang. Y., \& Chan. T. S. (2005). Entrepreneurship strategy making and performance in China's new technology venture-the contingency effect of environments and firm competences. Journal of High Technology Management Research, 16, 37-57.

Mahapatra. S. (1984). Investor reaction to corporate social accounting. Journal of Business Finance \& Accounting, 11(1), $29-40$.

Palmer. K., Oates. W. E., \& Portey. P. R. (1995). Tightening environmental standards: The benefit-cost or the no-cost paradigm? The Journal of Economic Perspectives. 9(4), 119- 132.

Petroni. A. (2001). Developing a methodology for analysis of benefits and shortcomings of so 14001 registrations: Lessons from experience of a large machinery manufacturer. Journal of Cleaner Production. 9(4), 351-364.

Porter. M. E. (1991). America's green strategy. Scientific American. 264(4), 96-168.

Porter. M. E., \& van der Linde. C. (1995). Toward a new conception of the environment competitiveness relationship. The Journal of Economic Perspectives. 9(4), 97-118.

Russo. M. V., \& Fouts. P. A. (1997). A resource-based perspective on corporate environmental performance and profitability. Academy of Management Journal. 40(3), 534-559.

Sambasivan. M., \& Fei. N.Y. (2007). Evaluation of critical success of implementation of ISO 14001 using analytic hierarchy process (AHP): A case study from Malaysia. Journal of Cleaner Production. 16, 1424-1433.

Schultze. W., \& Trommer. R. (2011). The concept of environmental performance and its measurement in empirical studies. Journal of Management Control. 22(4), 375-412.

Shrivastava. P., \& Hart. S. (1995). Creating sustainable corporations. Business Strategy \& the Environment. 4(3), 154-165. 
Spicer. B. H. (1978). Investors, corporate social performance, and information disclosure: An empirical study. The Accounting Review. 53(1), 94-111.

Tan. L. P. (2005). Implementing ISO 14001: Is it beneficial for firms in newly industrialized Malaysia? Journal of Cleaner Production. 13(4), 397-404.

Thoresen. J. (1999). Environmental performance evaluation: A tool for industrial improvement. Journal of Cleaner Production. 7(5), 365-370.

Tibor. T., \& Feldman. I. (1996). ISO 14000: A guide to the new environmental management standards. Chicago: Irwin Professional Publications.

Walley. N., \& Whitehead. B. (1994). It's not easy being green. Harvard Business Review. 72(3), 46-52.

Watson. K., Klingeberg. B., Polito. T., \& Guerts. T. G. (2004). Impact of environmental management system implementation on financial performance: A comparison of two strategies. Management of Environmental Quality, 15(6). $622-628$.

Zeng. S. X., Tam. C. M., Tam. V. W. Y., \& Deng. Z. M., (2005). Towards implementation of ISO 14001 environmental management systems in selected industries in China. Journal of Cleaner Production. 13(7), 645-656.

Zutshi. A., \& Sohal. A. (2004). Environmental management system adaption by Australasian organizations: Part 1: Reasons. Benefits, and impediments. Technovation, 24(4), 335-357. 